Article

\title{
Organizational Capabilities for Family Firm Sustainability: The Role of Knowledge Accumulation and Family Essence
}

\author{
Ismael Barros-Contreras ${ }^{1}$, Jesús Manuel Palma-Ruiz ${ }^{2, *(D)}$ and Angel Torres-Toukoumidis ${ }^{3}$ (D) \\ 1 Instituto de Gestión e Industria, Universidad Austral de Chile, Valdivia 5480000, Chile; ismaelbarros@uach.cl \\ 2 Facultad de Contaduría y Administración, Universidad Autónoma de Chihuahua, Chihuahua 31000, Mexico \\ 3 Social Science Knowledge and Human Behavior, Universidad Politécnica Salesiana, Cuenca 010105, Ecuador; \\ atorrest@ups.edu.ec \\ * Correspondence: jmpalma@uach.mx
}

check for updates

Citation: Barros-Contreras, I.;

Palma-Ruiz, J.M.;

Torres-Toukoumidis, A.

Organizational Capabilities for

Family Firm Sustainability: The Role of Knowledge Accumulation and Family Essence. Sustainability 2021, 13, 5607. https://doi.org/10.3390/ su13105607

Academic Editor: Jose Ramon Saura

Received: 13 April 2021

Accepted: 13 May 2021

Published: 18 May 2021

Publisher's Note: MDPI stays neutral with regard to jurisdictional claims in published maps and institutional affiliations.

Copyright: (c) 2021 by the authors. Licensee MDPI, Basel, Switzerland. This article is an open access article distributed under the terms and conditions of the Creative Commons Attribution (CC BY) license (https:/ / creativecommons.org/licenses/by/ $4.0 /)$.

\begin{abstract}
While prior studies recognize the importance of organizational capabilities for family firm sustainability, current research has still failed to empirically identify the role of different types of knowledge accumulation with regard to these organizational capabilities. Based on the dynamic capabilities theory, the main goal of this paper is to address this research gap and to explore the relationships between both internal and external knowledge accumulation, and ordinary organizational capabilities. This research also contributes to analyzing the complex effect of the family firm essence, influenced by both family involvement and generational involvement levels, as an antecedent of internal and external knowledge accumulation. Our analysis of 102 non-listed Spanish family firms shows that the family firm essence, which is influenced by the family involvement, strengthens only the internal knowledge accumulation but not the external one. Furthermore, our study also reveals that both internal and knowledge accumulation are positively related to ordinary capabilities.
\end{abstract}

Keywords: dynamic capabilities; internal knowledge accumulation; external knowledge accumulation; family essence; family firms; ordinary capabilities; structural equation modeling; partial least squares

\section{Introduction}

The strategic management literature proposes that the development of firms' dynamic capabilities is a crucial factor for a firm's success and survival in the long term [1-3], especially in today's increasingly dynamic markets with a growing number of emerging global competitors [4]. In this sense, dynamic capabilities enable firms to create, deploy and protect the intangible assets that support a superior business performance in the long term [5]. This long-term performance is particularly relevant in the case of family firms, the most widely spread type of firm all around the world [6]. Thus, the identification of enablers of dynamic organizational adaptation appears vital to their sustainable competitive advantage [7]. Nevertheless, the study of dynamic capabilities in family firms is yet in its infancy. Indeed, except for some very well-known studies [8-10], this lack of research in such a specific type of organizations could be viewed as a considerable weakness of the field, since family firms' strategy is usually described as based on considerably path-dependent abilities, having thus difficulties to adapt to fast-changing environments $[10,11]$.

In family firms, sustainability is a function of both firm success and family functionality and focuses on how family members exchange resources across systems [12]. Consequently, the resource processes (use or transformation of capital) and interpersonal processes (e.g., conflict management, communication, personal relationships) in either firm or family may facilitate or inhibit family firm sustainability [12]. Hence, the processes that may impact the dynamic capabilities in family firms are more complex than generally assumed. Prior literature has shown that different aspects related to knowledge seem to influence the dynamic capabilities of firms [13-15]. For instance, authors have developed a model 
where knowledge integration acts as a driver of dynamic capabilities based on family firm-specific factors such as internal social capital, relationship conflict, and affective commitment to change [7]. Nonetheless, it is common that the literature in this field stresses the quantitative aspects of dynamic capabilities, which may tend to excessively simplify the process [16]; furthermore, there is scant analysis about which factors may impact the evolution of dynamic capabilities in family firms [10].

Intending to compensate for the above-mentioned limitation, we focus on exploring how knowledge accumulation impacts the dynamic capabilities of family firms. In particular, since family-specific antecedents of knowledge integration enrich our understanding of the causal mechanisms underlying dynamic adaptation [7], we differentiate between the potential effects that internal knowledge accumulation and external knowledge accumulation [17-19] may have on the ordinary capabilities of these firms. Accordingly, since family firms are regarded as having both different goals, values, and decision making in comparison to their non-family counterparts [20], the present study tries to unravel the effects that the family essence may have in the knowledge accumulation of family firms, which will reveal in greater detail the complex antecedents and their interactions that intervene in the development of the dynamic capabilities in family firms.

The remainder of this article is structured as follows. The next section presents the theoretical background of the study to formulate the corresponding research hypotheses. Section 3 explains the methodology from data collection to the different measures and analyses used in the study. The results are shown in Section 4. Finally, the last section includes the discussion and conclusions of the study, including its limitations, implications, and directions for future research.

\section{Theoretical Background and Hypotheses Development}

\subsection{Organizational Capabilities in Family Firms}

The dynamic capabilities lens highlights that to succeed firms must be able to incessantly develop, improve and renew their products and processes [5]. This is based on the idea that dynamic capabilities help firms protecting their products and processes against imitation by their competitors as well as against the technological obsolescence that emerged of the life cycle of their industry [21]. More specifically, dynamic capabilities allow firms to broaden, change, or create ordinary capabilities by accessing and recombining knowledge, thus enabling success in its ordinary capabilities and generation of value over time [5,22].

Investigating the development of dynamic capabilities in family firms entails analyzing the knowledge accumulation as a driver of firm capabilities [23]. Knowledge accumulation has been regarded as a key tool for the achievement of ordinary capabilities [1,24]. However, knowledge accumulation is usually accomplished distinctly in family firms in comparison to their non-family counterparts. Indeed, in family firms, knowledge accumulation is a dynamic capability that helps to continuously create new knowledge out of existing family firm-specific resources $[25,26]$. These specific resources could be summarized as a family essence of family firms [15]. In this respect, and building on such study [15], we shed light on the specificities of how knowledge accumulation influences dynamic capabilities in this type of business. Thus, we designed a theoretical model where three main subsequent effects are discussed: whether different types of family involvement (i.e., the proportion of family members in both governance and management boards, and the number of generations involved in both governance and management boards) provides family essence, whether family essence impacts on knowledge accumulation and whether the influence of knowledge accumulation influences dynamic capabilities in family firms. In the following subsections, we will analyze, one by one, each of the aforementioned relationships. 


\subsection{Family Essence and Its Determinants}

Family essence refers to the controlling family's willingness to use its influence within the firm to seek its specific goals $[15,27]$. Family essence focuses on how the family impacts the way an organization is governed or managed [28]. In family firms, the degree of family essence is influenced by the family involvement in governance and management [29]. In this regard, we focus on how two main forms of family involvement in the board influence the family essence: on the one hand, the proportion of family members in the boards (i.e., the family director ratio) [30] and, on the other hand, the number of generations in the boards, or generational involvement [31].

Moreover, regarding the proportion of the family involvement in the governance and management boards, a higher family director ratio is expected to enhance the family essence of a firm. In general, family directors demonstrate a superior duty to the business and a deeper desire towards the firm's success in contrast to non-family directors [30]. Furthermore, a higher percentage of family members on the board is prone to reinforce the bonds among family members [32] and enhances the family orientation where family values, emotional ties, and family feelings are imprinted to the firm [33] through interaction and mutual trust [34]. Instead, a higher generation involvement in the governance and management boards is also expected to increase the family essence of a firm. Prior literature points out that family firms with diverse generations involved in management display higher levels of unity, emotional commitment [35], a deeper sense of shared purpose [36], and a greater desire to ensure the success of the business [32]. For all these, we conclude that the aforesaid factors, this is, a higher proportion of family directors and a higher generational involvement in the boards enhance the family essence of a firm. Consequently, the first double hypothesis can be derived as follows:

Hypothesis 1a (H1a). In family firms, a higher percentage of family involvement in the governance and management boards will increase its essence as a family firm.

Hypothesis $\mathbf{1 b} \mathbf{b} \mathbf{H 1 b})$. In family firms, a higher number of generations involved in the governance and management boards will increase its essence as a family firm.

\subsection{Knowledge Accumulation in Family Firms}

In family firms, organizational culture is reflected through family essence in the family firm as considered "a personal belief and support of the organization's goals and visions, a willingness to contribute to the organization, and a desire for a relationship with the organization" [37] (p. 51). The family firm essence reflects the family's intention to manage the firm to achieve its vision beyond the life expectancy of the current generation $[38,39]$. As the family firm strengthens its essence, knowledge sharing mechanisms are likely to be open, candid, and functional, which will increase their positive relationship [32]. As well, family essence in which family members are involved by higher level represents a signal that the family will exercise its influence to establish processes that guarantee knowledge transfer to the succeeding generations, hence building and preserving the socioemotional wealth of family members $[39,40]$. In the opposite direction, lower levels of commitment to the family firm negatively affect knowledge accumulation [37,41].

Knowledge accumulation is defined as an instrument of organizational learning aiding the development of organizational routines, and represents the basis for the development of dynamic capabilities [22] that permit an organization to create, extend or modify its resources [42]. The knowledge accumulation processes that drive firms to advance, increase, redesign and utilize both internal and external knowledge can be differentiated into internal knowledge accumulation and external knowledge accumulation processes [21].

Furthermore, family members, who want to retain the family in the firm based on their strong family essence, are prone to exceeding their regular job responsibilities, which aid in the transmission of experience and internal knowledge [23]. The typical co-worker interactions surpass the limitations of the workplace, which promotes enhanced collabora- 
tion and exchange of information and experiences [43]. In this vein, such closer connections facilitate family members to attain experience and foster practical skills inside the family firm [23]; moreover, the communication across generations within the family firm can aid in knowledge creation [44] and knowledge accumulation in the long-term [23].

On the other hand, external knowledge accumulation relates to the finding, assembly, and use of knowledge from external sources [45]. The authors exposed the relationship between knowledge transfer and workers mobility demonstrating the relevance of external knowledge accumulation [46]. In this regard, knowledge transfer between firms and external sources is dependent on trust and social ties [26]. However, this knowledge from abundant external sources needs to be integrated and accumulated into the firm through hundreds of daily management decisions [47]. In the case of family firms, prior literature suggests that, based on their desire to preserve the socioemotional wealth [40], family firms are reluctant to professionalization [39]. In particular, the signing of directors external to the family rises conflicts concerning the firm's goals because of the opposing motivations and professional objectives of both the family and non-family employees [48]. As such, the family's goal to shape an environment to aid in the transmission of the family essence and values is linked with emphasizing long-term planning, the internal knowledge accumulated into the firm, and a lower propensity to use external sources of knowledge. For all these, we propose the following second double hypothesis:

Hypothesis 2a (H2a). In family firms, a stronger essence as a family firm will be positively related to internal knowledge accumulation.

Hypothesis $\mathbf{2 b} \mathbf{( H 2 b )}$. In family firms, a stronger essence as a family firm will be negatively related to external knowledge accumulation.

\subsection{Knowledge Accumulation and Organizational Capabilities}

The specific accumulation of knowledge in family firms is positively associated with high levels of ordinary capabilities $[24,49,50]$. Fostering idiosyncratic knowledge promotes a more suitable mixture and alignment of family resources, and indirectly aids in the generational continuity of the business [7]. Furthermore, knowledge integration of specialized knowledge was identified as a success factor for family firms operating in different markets [7]. Ordinary capabilities are somehow regarded as the best practices of the firm and are a precondition of firm performance $[1,19]$. In this regard, research confirms that knowledge accumulation is a key tool for the achievement of ordinary capabilities [24,49].

Nevertheless, today's dynamic markets require family firms to convert ordinary capabilities into dynamic ones within the firm [1]. More specifically, a firm can take advantage of continuously improving its ordinary capabilities and create value by improving its ability for innovation, marketing of new products, anticipating and reacting to market changes including those unexpected ones [25], so as promoting dynamic capabilities [8]. The benefits of ordinary capabilities are contingent upon the knowledge accumulation processes that let firms advance, increase, reshape and apply new internal and external knowledge [21].

In this regard, the accumulation of both internal and external knowledge plays a crucial role when developing ordinary capabilities, such as the capacity of designing new products or improving the current ones, polishing firm processes, and adjusting organizational methods to match with the context of their final market [51]. Once family members attain new knowledge and advance abilities when joining the firm, per se, such knowledge can be shared and transferred to other colleagues in the firm [23] and transmitted across the generations [41]. Once incorporated, this knowledge aids in the development of new strategies, as well as managerial and operational routines in the firm [52]. All things considered, in family firms both internal and external knowledge accumulation, strengthen their ordinary capabilities. Figure 1 shows the research model. Given all these, we propose the following third double hypothesis: 
Hypothesis 3a (H3a). In family firms, internal knowledge accumulation strengthens their ordinary capabilities.

Hypothesis $\mathbf{3 b} \mathbf{b} \mathbf{H} \mathbf{3 b})$. In family firms, external knowledge accumulation strengthens their ordinary capabilities.

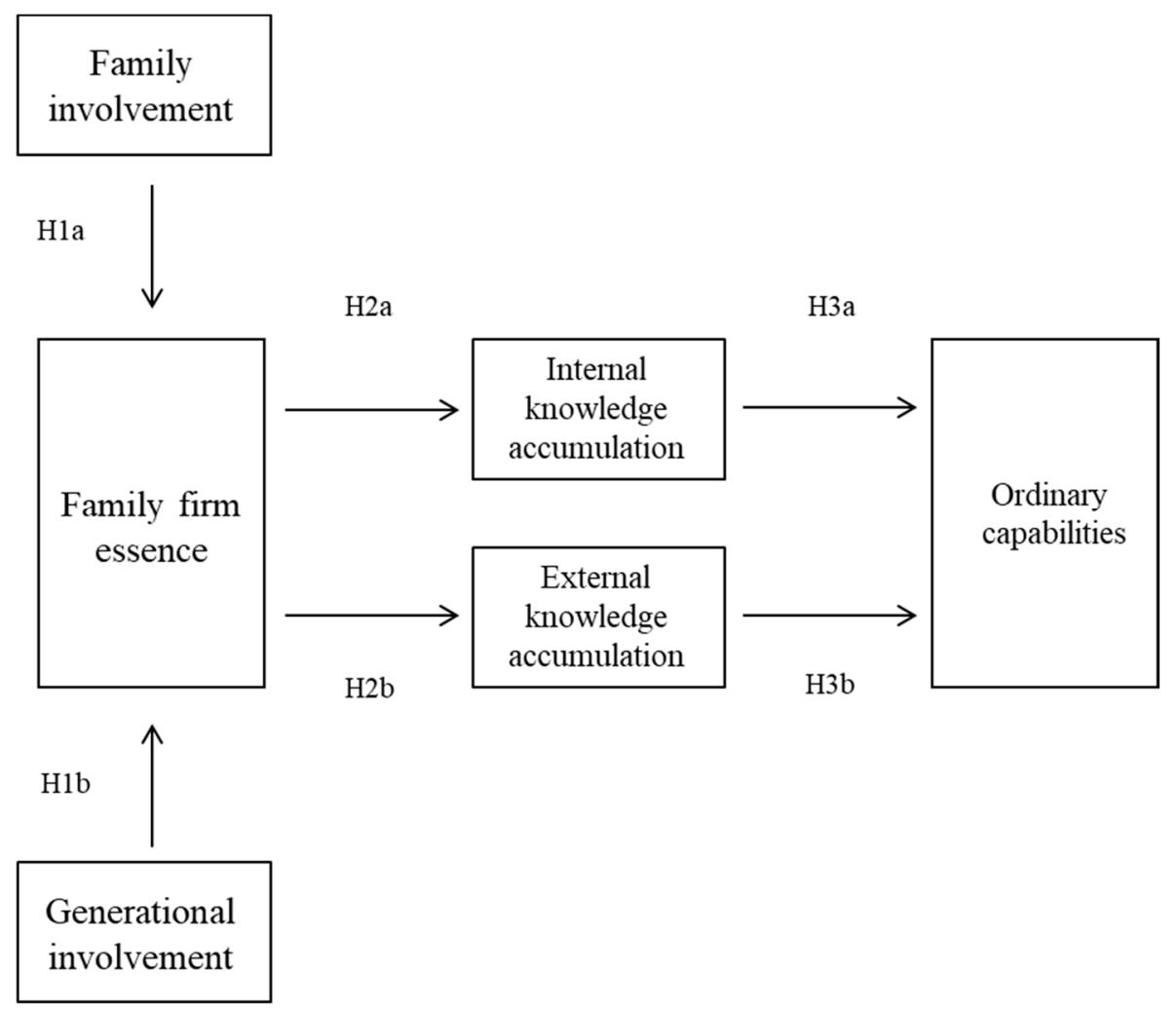

Figure 1. Research model and hypotheses.

\section{Methods}

\subsection{Sample and Data Collection}

Family businesses in Spain are the predominant business structure with strong family participation and leadership in the property and the administration and management teams [53]. Studies estimate that the share of family businesses in the overall Spanish business structure represents $90 \%$, contributing about $60 \%$ of GDP [54]. Thus, the Spanish context offers a unique organizational structure of family businesses across the globe, with relevant participation in the development of public policies. These aspects make the Spanish context appropriate for this study. The empirical analysis in this study used a sample of non-listed medium and large Spanish family firms, according to the 2012 ranking by "Actualidad Económica" — a well-known magazine in business and finance. The ranking, sorted by sales volume, identified the leading 5000 firms in Spain. The final sample included 1656 firms. Following prior research [55], family firms were selected based on two conditions: (a) one family had at least 50 percent of the firm 's equity, and (b) members of such controlling family were involved in the firm's management. Listed companies were excluded due to their ownership and management structure since they have defined bodies that separate the family from the company, limiting the family-business relational ties (aspects of importance for this study). In general, it is recognized that listed family businesses do not maintain the characteristics of familiarity of their initial stages, which have been diminished as their ownership has been segmented [56]. Therefore, our interest encompasses medium and large unlisted Spanish family companies. Scarce research has 
been carried out on this segment of family firms since $80 \%$ of the studies have focused on listed family companies [57].

Data were collected through a questionnaire sent by ordinary mail to the final sample of firms conducted from May to September 2013. This particular year represents a relevant timeframe marked by the Spanish crises from 2008 to 2013. During this period, Spanish firms dealt with challenging and shifting environments amid the financial crisis and the restructuring of the Spanish banking system, in addition to the global crisis, which forced family firms to face an entirely unknown environment. Consistent with prior research [58,59], we opted for a single respondent survey, the CEO. Previous studies have adopted this approach and relying on a single respondent is accepted in research areas when the main informant is surveyed [60]. An invitation letter was sent to the CEOs introducing the research objective and advising their participation and assuring the confidentiality of the responses. The position of these CEOs certified them to comment on firm-base practices and experiences, becoming the main informants for the study due to their overall vision of the firm strategy [30]. The measurement of each of the variables considered was carried out according to scales obtained from the previous literature (refer to Section 3.2). The questionnaire was divided into four sections. Section one was dedicated to gathering general information about the firm, for example, information about the respondent, the company, the property and the family generations active in the firm. Section two was aimed at collecting aspects of the family essence. The third section was dedicated to obtaining information regarding the main variables of the study, for example, internal and external knowledge accumulation. Finally, information was obtained regarding the ordinary capabilities variable.

Starting from the initial sample of 1656 Spanish non-listed large and medium family firms, 135 responses ( $8.15 \%$ of the sample) were collected. The response rate is consistent with previous research on privately held firms [61,62]. After verifying the validity of the responses and filtering for those that did not comply with the sample characteristics (17 were non-family firms and 6 were listed firms), the final sample included 102 valid surveys. The final sample used in this study is adequate to the research objectives since $100 \%$ of the responses corresponded to unlisted family companies, and $99 \%$ stated that their companies were family-owned, with the presence of family members on their management boards (95\%) and in their governance boards (98\%). In addition, $93 \%$ of the respondents expected that the future CEO of their company would be a family member. The indicated aspects conform to the restrictions established in the operational definition adopted for this study, that is, participation of family members in the property, in the management and governance, and the intention of transgenerational family control [63]. Although the sample size relative to the population rarely affects the accuracy of the sample [64], we ran additional analyses to test for non-response bias. More specifically, the sample was split into three groups to compare the initial and final responses received. The ANOVA analysis displayed irrelevant differences between the initial and final respondents at a $99 \%$ level of significance. Thus, non-response bias was not be a problem in this study.

Given that this study relied on CEOs as keys respondents and on data delivered by an individual in a single period [65], common method bias could be a concern. To reduce this potential threat, preliminary adjustments were adequately addressed in the survey design. Firstly, the anonymity and confidentiality of the responses were guaranteed in order to prevent the tendency of respondents to mistake their views and truthful opinions [66]. Secondly, independent and dependent variables were set into different sections of the survey, making it difficult for the respondents to link together both concepts [67]. Thirdly, we also included different response formats within and across the different sections of the survey [68]. While mainly using 5-point Likert scales, additional guides were used, such as "completely agree/completely disagree", or "completely wrong/completely right" [67]. Likert-type scales are suitable for measuring reactions, attitudes and behaviors, which are fundamental aspects to be collected in the proposed research study. 
Additionally, the common method variance was also tested by employing a post hoc test of the data: Harman's single-factor test $[69,70]$. Such a test deduces that common method bias is present when the factor analysis shows a single factor that accounts for most of the variance [67]. In this study, Harman's test showed that the first factor accounted for $24.8 \%$ of the total variance; hence, common method bias is either absent or insignificantly small in the data [67].

\subsection{Measures}

The variables and scales were based on existing and tested instruments from previous literature, shaping the research model in our study (refer to Table A1 in Appendix A). Firstly, the concept of the family business was configured according to standard criteria such as "family participation in the business", which have been used in previous studies [38,63], adopting an operational definition of a family business based on two characteristics that companies must meet to be considered family businesses: first, participation of family members in the ownership of the company, in the management and governance boards and, second, family intentions for transgenerational control. After applying the operational definition that has helped us to identify family businesses, we adopted the F-PEC scale [37,71-73], which is widely used in the literature to measure both the family firm involvement and essence. These variables were structured as follows:

Family involvement in the boards. The percentage of governing/management board positions occupied directly and/or indirectly by family members.

Generational involvement in the boards. The number of generations of family members involved on the directors and management boards.

Family firm essence. This variable was adapted from the culture sub-scale developed in the F-PEC scale. Consistent with previous studies [27,71], the representative features of the culture sub-scale in the F-PEC denote whether the family members (a) feel loyalty towards the family business, (b) concur with the family business's objectives, plans, and politics, (c) share the same business values, (d) are preoccupied about the future/destiny of the business, and (e) are disposed to commit great efforts for the business to succeed. The assessment of such five features was completed by using a Likert scale ( 1 = "Completely wrong" to 5 = "Completely right").

Furthermore, we measured the sources of internal and external knowledge accumulation in the family business as proposed by [23], which can contribute to the accumulation of knowledge through generations, and assessed as follows:

Internal knowledge accumulation. Based on the scale of knowledge management processes to family firms [23], the respondents (family members who work on the firm) were asked to evaluate the following three items on a 5-point Likert scale ( $1=$ "Completely disagree" to 5 = "Completely agree"): (a) attend practical training courses within the family firm, (b) show commitment to the family firm, and (c) feel that the family firm is their own.

External knowledge accumulation. The measure of external knowledge accumulation is also based on [23]. Specifically, the family members who work on the firm were asked to evaluate the following two items on a 5-point Likert scale ( $1=$ "Completely disagree" to 5 = "Completely agree"): (a) family members working in the firm who attend academic courses or practical training courses outside of the firm, (b) the family firm is willing to hire non-family member executives.

Additionally, ordinary capabilities were built according to the micro-foundations proposed by [5]. The items included the identification of ordinary capabilities through the continuous development of activities and organizational processes derived from learning and knowledge capabilities of the company, and measured as follows:

Ordinary capabilities. This variable is measured on a scale constructed consistent with the micro-fundamentals proposed by [5], to assess the degree to which an organization attempts to identify ordinary capabilities using the development of permanent organizational activities and processes derived from the learning and knowledge capabilities of the firm. The family members who work on the firm were asked to evaluate the following seven 
items, with all of their routines recognized as evidence of ordinary capabilities [24,49], on a 5-point Likert scale $(1=$ "Completely disagree" to $5=$ "Completely agree") related to continuous development: (a) internal activities of research and development, (b) activities to identify changes in customer needs, (c) processes to take advantage of technological developments, (d) adaptation processes for the business model, (e) processes of asset management, (f) activities such as job rotation, regular multi-level meetings, information bulletins/blogs, configuration of multi-functional teams and, (g) processes of resource adaptation to take advantage of new opportunities.

Finally, we included three control variables that are normally used in previous research related to the behavior of family businesses [74], which were assessed as follows:

Control variables. Different additional variables were included to ensure a proper model specification and to consider possible alternative explanations for the results of this family firm behavior research [75]. More specifically, as regarded as directly influencing the family firm behavior, firm age, firm size, and industry were controlled [74]. Firm age, measured as the number of years since founding, was included since the family can have a deeper attachment to the firm over time [76] as well as influence its disposition towards knowledge management. In addition, firm size, measured as the actual number of employees, was controlled since a firm that grows in size can formalize and implement specific processes of knowledge management. In this regard, the relationship between the family and the firm can become more distant when the size of the firm grows, for example, due to the need to professionalize the firm [27]. Finally, given the business environment may impact the predisposition towards knowledge accumulation, we controlled for the industry variable classifying the firms following the categories proposed by the Standard Industrial Classification (SIC Code). The categories include agriculture, construction, manufacturing, transportation, commerce, service, and others.

\subsection{Statistical Method}

The proposed relationships in the data were tested through structural equation modeling (SEM). One of the main advantages of SEM is that, compared with regression analysis, this is a more appropriate method to examine theoretical models with latent compound constructs [77]. This is because performing a linear regression analysis on the data requires a simplification of the content of each construct, which means that some information may be lost by creating an index for each construct or variable $[75,78]$. Specifically, we used the partial least squares (PLS) approach, given that some of its main characteristics make it especially suitable for this research. First, given that the sample size is relatively small, very little above the limit of 100 (102), in line with prior literature, PLS is seen as an adequate technique for obtaining reliable results [79]. Second, PLS-SEM works better when analyzing predictive research models in the early stages of theoretical development $[80,81]$. Third, PLS can capture the normative implications of the total system of variables, and holistically clarify the entire model [82], which is important in our case as we estimate a model of simultaneous relationships and aim to have a complete overview [4].

In this research, the measurement and structural models were analyzed using SmartPLS software [83]. First, the reliability and validity of the measurement model were analyzed. Second, the overall assessment of the structural model was analyzed. Finally, the hypotheses were contrasted by using a "bootstrapping" 5000 technique [84].

\section{Results}

\subsection{Measurement Model}

Before estimating the quality of the structural model, we assessed the reliability and validity of our measurement models [80]. Construct reliability, assessed with Cronbach's alpha (range 0.524 to 0.956 ), and composite reliability (range 0.807 to 0.971 ) exceeded the recommended minimum of 0.70 [85]. All indicators were significantly associated with their respective constructs $(p<0.01)$. Convergent validity (AVE) exceeded the accepted minimum level of 0.50 in all cases [77]. Since none of the loadings were lower than 0.4 , none had to 
be deleted. The discriminant validity was also estimated by testing uni-dimensionality based on the cross-loadings of indicators and the Fornell-Larcker criterion [77,85]. All constructs showed sufficient levels of discriminant validity. Table 1 lists the measures and their associated Cronbach's Alphas (CAs), construct reliability, average variance extracted (AVE), and factor loadings. Additionally, inter-construct correlations and average variance extracted are shown in Table 2.

Table 1. Latent variable, measurement item, composite reliability, average variance extracted (AVE), and Cronbach's Alphas.

\begin{tabular}{|c|c|c|c|c|c|}
\hline Construct and Indicator & Factor Loading & t-Statistic & Composite Reliability & AVE & Cronbach's Alpha \\
\hline Family involvement & & & 0.923 & 0.858 & 0.836 \\
\hline Fin_1 & 0.911 & 7.323 & & & \\
\hline Fin_2 & 0.941 & 11.453 & & & \\
\hline Generational involvement & & & 0.971 & 0.919 & 0.956 \\
\hline Gin_1 & 0.917 & 10.780 & & & \\
\hline Gin_2 & 0.982 & 11.108 & & & \\
\hline Gin_3 & 0.976 & 11.283 & & & \\
\hline Family firm essence & & & 0.855 & 0.542 & 0.789 \\
\hline Ffe_1 & 0.752 & 8.072 & & & \\
\hline Ffe_2 & 0.703 & 7.493 & & & \\
\hline $\mathrm{Ffe}_{-} 3$ & 0.719 & 8.478 & & & \\
\hline $\mathrm{Ffe}_{4} 4$ & 0.701 & 6.605 & & & \\
\hline Ffe_5 & 0.800 & 10.046 & & & \\
\hline $\begin{array}{l}\text { Internal knowledge } \\
\text { accumulation }\end{array}$ & & & 0.856 & 0.748 & 0.664 \\
\hline Ika_1 & 0.879 & 13.154 & & & \\
\hline Ika_2 & 0.850 & 11.401 & & & \\
\hline $\begin{array}{l}\text { External knowledge } \\
\text { accumulation }\end{array}$ & & & 0.807 & 0.676 & 0.524 \\
\hline Eka_1 & 0.850 & 8.997 & & & \\
\hline Eka_2 & 0.794 & 8.191 & & & \\
\hline Ordinary capabilities & & & 0.911 & 0.596 & 0.885 \\
\hline Oca_1 & 0.720 & 13.391 & & & \\
\hline Oca_2 & 0.883 & 30.783 & & & \\
\hline Oca_3 & 0.799 & 16.324 & & & \\
\hline Oca_4 & 0.786 & 17.345 & & & \\
\hline Oca_5 & 0.613 & 5.387 & & & \\
\hline Oca_6 & 0.719 & 9.811 & & & \\
\hline Oca_7 & 0.851 & 20.550 & & & \\
\hline Control variables & & & - & - & - \\
\hline Fage & 0.024 & 0.417 & & & \\
\hline Fsiz & 0.202 & 2.463 & & & \\
\hline Find & 0.018 & 0.335 & & & \\
\hline
\end{tabular}

Table 2. Inter-construct correlations and average variance extracted (AVE).

\begin{tabular}{lcccccc}
\hline \multicolumn{1}{c}{ Construct } & $\mathbf{1}$ & $\mathbf{2}$ & $\mathbf{3}$ & $\mathbf{4}$ & $\mathbf{5}$ & $\mathbf{6}$ \\
\hline 1. Ordinary capabilities & 0.772 & & & & & \\
2. Internal knowledge accumulation & 0.282 & 0.865 & & & & \\
3. External knowledge accumulation & 0.424 & 0.132 & 0.822 & & & \\
4. Family firm essence & 0.082 & 0.478 & 0.016 & 0.736 & & \\
5. Generational involvement & 0.045 & -0.033 & 0.089 & -0.107 & 0.959 & \\
6. Family involvement & -0.270 & 0.148 & -0.272 & 0.255 & 0.044 & 0.926 \\
\hline
\end{tabular}




\subsection{Structural Model and Hypotheses Results}

We evaluated the quality of the structural model through predictive validity using the coefficient of determination in endogenous variables $\left(R^{2}\right)$ [86], regression coefficients' significance using the bootstrapping technique [77], and the Stone-Geisser Criterion $\left(\mathrm{Q}^{2}\right)$ using the blindfolding procedure with an omission distance of 7 [87]. The value for $R^{2}$ for ordinary capabilities is significant $(0.232)$. Notwithstanding the weaker values, the crossvalidated redundancy measures show that the theoretical/structural model has predictive relevance $\left(Q^{2}>0\right)$ [77]. For hypotheses testing, we assessed the sign and magnitude of path coefficients and their t-values obtained by applying nonparametric bootstrapping, calculating the effect sizes and total effects [86]. Figure 2 reports the PLS path coefficients and $\mathrm{t}$-values.

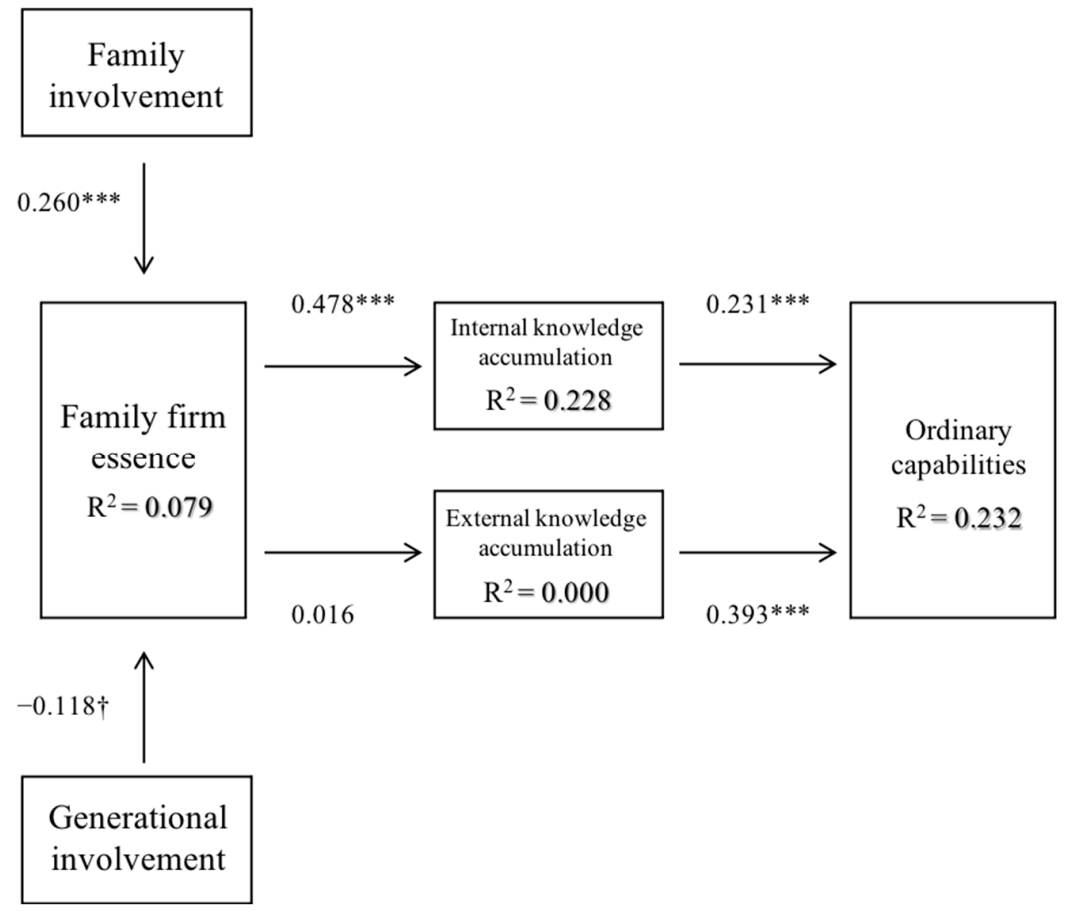

Figure 2. An empirical model of knowledge accumulation in family firms. Note: ${ }^{* * *} p<0.01$ (t statistic one-tail) $+p<0.1$ (t statistic two-tailed).

Once the model's validity is confirmed, to determine the effects, we tested our three double hypotheses. The significance of the relationships in our model was estimated using the bootstrapping technique [77]. Specifically, we tested our three double hypotheses by assessing the sign and magnitude of the path coefficients and their $\mathrm{t}$-values by applying non-parametric bootstrapping and then calculating the effect sizes and total effects [86]. Table 3 reports the PLS path coefficients and $t$-values, along with the $R^{2}$ for the endogenous constructs.

Table 3. Results of hypotheses testing.

\begin{tabular}{lccc}
\hline \multicolumn{1}{c}{ Hypotheses } & Path Coefficient & t-Value & Outcome \\
\hline (H1a) Family involvement $\rightarrow$ Family firm essence & 0.260 & $2.395^{* * *}$ & Supported \\
(H1b) Generational involvement $\rightarrow$ Family firm essence & -0.118 & $1.669 \dagger$ & Not supported \\
(H2a) Family firm essence $\rightarrow$ Internal knowledge accumulation & 0.478 & $5.644^{* * *}$ & Supported \\
(H2b) Family firm essence $\rightarrow$ External knowledge accumulation & 0.016 & 0.230 & Not supported \\
(H3a) Internal knowledge accumulation $\rightarrow$ Ordinary capabilities & 0.231 & $2.232^{* * *}$ & Supported \\
(H3b) External knowledge accumulation $\rightarrow$ Ordinary capabilities & 0.393 & $4.178^{* * *}$ & Supported \\
\hline
\end{tabular}


The effect of a higher percentage of family involvement in the governance on family firm essence was positive and statistically significant $(\beta=0.26 ; \mathrm{t}=2.395 ; p<0.01)$; thus, H1a is supported. The results indicated that family firms with higher family involvement in the governance had a more pronounced essence than family firms. Nevertheless, contrary to our expectations, the effect of a higher number of generations involved in the governance on family firm essence was negative and statistically significant $(\beta=-0.118 ; \mathrm{t}=1.669$; $p<0.1$ ); thus, $\mathrm{H} 1 \mathrm{~b}$ is not supported. With regards to $\mathrm{H} 2 \mathrm{a}$, the results showed that there was a positive and statistically significant effect $(\beta=0.478 ; \mathrm{t}=5.644 ; p<0.01)$ between family firm essence and internal knowledge accumulation; thus, H2a is supported. Relatedly, the result regarding our hypothesis about the relationship between family firm essence and external knowledge accumulation was positive and non-statistically significant $(\beta=0.016$; $\mathrm{t}=0.230 ; p>0.1)$; thus, $\mathrm{H} 2 \mathrm{~b}$ is not supported. Finally, we found that there were positive and statistically significant effects in both relationships between internal knowledge accumulation and ordinary capabilities $(\beta=0.231 ; \mathrm{t}=2.232 ; p<0.01)$ and external knowledge accumulation and ordinary capabilities $(\beta=0.393 ; \mathrm{t}=4.178 ; p<0.01)$, thus both $\mathrm{H} 3 \mathrm{a}$ and $\mathrm{H} 3 \mathrm{~b}$ were supported, respectively.

\section{Discussion and Implications}

\subsection{Results Discussion}

In this paper, we address and study how the family effect affects internal and external knowledge accumulation and thus ordinary capabilities in family firms. Family firm literature stresses that family business is heterogeneous [88], the family and generational involvement in the firm impact family business behavior to make it distinctive and idiosyncratic. In particular, the family involvement in government and management boards allows the family to transfer family values to the firm, constituting the family firm essence [27]. In contrast, our study finds that family generations negatively impact family firm essence. This is to say, new family generations restricted the transfer of culture and family values to the firm, which can be based on the arrival of new generations increasing the possibility of family conflicts [89], negatively affecting the essence of the family business [90]. On other hand, the results indicate that as the family generations incorporate into the firm, the family essence deteriorates [91]; in effect, family altruism is eroded when the family grows and ownership is spread across the generations. These results are consistent with other studies [39] whose results indicate that the presence of multiple generations in firm ownership causes commitment and shared values, which are initially present, to be reduced due to conflicts and the passage of time.

Family firm essence affects the decision-making process and especially conditions how the firm's resources and capabilities are deployed. In our study, family firm essence affects differently the accumulation of knowledge in the family business. First, concerning the internal accumulation of knowledge, it is confirmed that family firm essence promotes the accumulation of internal knowledge. The high involvement of family members in the firm, especially in its government and management boards, allows them to influence the management of the firm's resources and capabilities in an idiosyncratic way, promoting the accumulation of knowledge internally in the firm [23]. The transfer of knowledge from parents to children, especially of the tacit knowledge, is done in learning by doing where parents prepare their children for the future of the firm. The affective components, emotional attachment, and psychological ownership of family members with the company strengthen this orientation and generate a context where the internal accumulation of knowledge takes place. Secondly and conversely, these emotional and affective endowments are averse to the accumulation of external knowledge. The need to maintain family control over the firm and the preservation of the socio-emotional endowments that family members deposit in the firm, lead them to avoid knowledge from external sources. Family owners may be reluctant and/or unable to professionalize the management structure of their firms, for example, hiring non-family executives [92]. 
Internal and external knowledge accumulation promotes the renewal of ordinary capabilities in family firms. In fact, knowledge accumulation is a key tool for the achievement of ordinary capabilities [24,49]. Moreover, knowledge accumulation is the learning mechanism that supports the generation of dynamic capabilities [22]. Our findings are consistent with other studies [93], which suggest that new value creation strategies are generated by the process of the recombination of resources. In this sense, specifically, knowledge accumulation, which is founded on the strong and close relationships between the family members, facilitates communication and learning [34,94], and thus, the ordinary capabilities of the family firm. In family firms, as we observe, the accumulation of knowledge is idiosyncratic. The closeness of family members, the history of life between the family and the firm, and the mental framework shared by family members in the company, create an enabling context where knowledge can be accumulated and shared among family members.

\subsection{Contributions and Implications}

This research offers two contributions to the study of family firms. First, and consistent with other authors' suggestions [23], we provide quantitative evidence for the relation between family firm resources and knowledge accumulation. In line with other studies [95], this work recognizes the heterogeneity of family firms, which implies that the generation of resources and capabilities in the family business depends on the degree of family involvement in governance and management boards, and at the same time, influence internal knowledge accumulation in an idiosyncratic manner. Second, in agreement with previous studies $[7,8,10,96]$, we extend the incorporation of the dynamic capabilities approach in the family business strategic management [97], improving understanding of how family resources affect dynamic capabilities, and therefore, ordinary capabilities.

Our results also have implications for the managers of the family firms. In particular, they need to understand that knowledge accumulation is related to the specific family resources involved in the firm. This understanding will permit managers to create a collaborative environment for the exchange of knowledge, especially tacit knowledge, coming from both family members and non-family members. The managers should promote a climate of trust and commitment that facilitates the interaction of the firm members and the family members, providing the necessary incentives that stimulate the creation, transfer, and articulation of knowledge in the family firm. Thus, those strong affective ties-the trust and the closeness of the relationships-will create a sense of belonging to the firm where the firm is part of the individual and the individual is part of the firm beneficial for knowledge accumulation [15,23].

\subsection{Limitations and Future Research Avenues}

The aforementioned discussed findings must be considered in light of the following limitations that provide future research avenues. First, we rely on data from a single country, Spain, which may limit our results' generalizability. Although we do not expect a significant variation in results between Spain and other western countries, cultural factors may influence our arguments, and especially in countries with natural cultures that significantly differ from Spain's [98]. Second, we recognize the limitations associated with using data from 2013. As previously noted, at this particular point in time, Spanish firms dealt with extremely difficult circumstances as a result of the global financial crisis and the restructuring of the Spanish banking system causing a contraction in bank lending. Consequently, financially constrained firms tend to decrease their profitability, reduce their investments, employment levels, and wages. In this sense, since such constrained environmental characteristics may somehow bias the results of our study, we call for researchers to replicate this model using data from different timeframes (i.e., times of economic growth, the COVID-19 health crisis, among others) and compare their findings with the ones shown in our research. This future research avenue may add to the literature by determining the generalizability of our findings. Third, while relying on a single 
informant is quite common in research surveying key informants [60], this could be a limitation since we infer firm-level behavior based on CEO responses [99]. In addition, relying on subjective data on some of our key constructs could also be considered a weakness since it could bias our results. Nevertheless, CEOs' in-depth knowledge on decision-making and firm processes in family firms, seems to legitimize the use of subjective data obtained from a single informant. Further, no cause for concern arose in testing for common method bias [100]. Fourth, our research has a cross-sectional nature, which suggests a need for further evidence on the causal relationships between the dependent and independent variables using longitudinal research. Nonetheless, we tested for common method bias [70] and did not find any concern. Fifth, apart from both internal and external knowledge accumulation, while our research only focuses on the role of only one relevant family-firm specific variable in the model, namely family essence, prior literature suggests that other sources of family influence such as family goals [101] or family values [102] may also impact on this model. Therefore, the next step would be to explore the influence of the aforementioned variables on the development of dynamic capabilities in family firms. In this sense, we are confident that our theoretical model will stimulate other scholars in family firm literature to explore how some other family-related variables influence the development of dynamic capabilities as well as analyze other potential outcomes of the latter apart from the most widely measured firm performance.

\section{Conclusions}

Dynamic capabilities are regarded as crucial for the sustainability of family businesses in the long term [5]. Drawing from a sample of 102 non-listed family firms in Spain, this study identified and found (partially) support for the effect of family essence $n$ knowledge accumulation in family firms. In addition, this research theorizes and demonstrates that while internal knowledge accumulation enhances ordinary capabilities in family firms, external knowledge accumulation seems not to be directly related to these capabilities. Relatedly, this study reveals that family firm essence plays a relevant role when developing internal knowledge accumulation capabilities in these firms. These findings shed light on family firm sustainability by deepening into the topic of dynamic capabilities and imply that future research may uncover additional interesting drivers to this crucial issue.

Author Contributions: The manuscript was written through joint contributions from all authors. I.B.-C. proposed the main idea, designed the empirical study, and wrote the initial draft. J.M.P.-R. and A.T.-T. improved, formatted, and copy-edited the paper. All authors have read and agreed to the final version of the manuscript.

Funding: This research received no external funding.

Institutional Review Board Statement: This study did not require ethical approval.

Informed Consent Statement: Informed consent was obtained from all subjects involved in the study.

Data Availability Statement: The data presented in this study are available on request from the corresponding author. The data are not publicly available due to restrictions of privacy.

Conflicts of Interest: The authors declare no conflict of interest with respect to the research, authorship, and/or publication of this article.

\section{Appendix A}

Table A1. Variables and scales in the study.

\begin{tabular}{l} 
Variables \\
\hline Familiness \\
Family involvement in the boards: \\
Fin_1 What percentage of positions on the governance board is occupied directly and/or \\
indirectly by family members are?
\end{tabular}


Table A1. Cont.

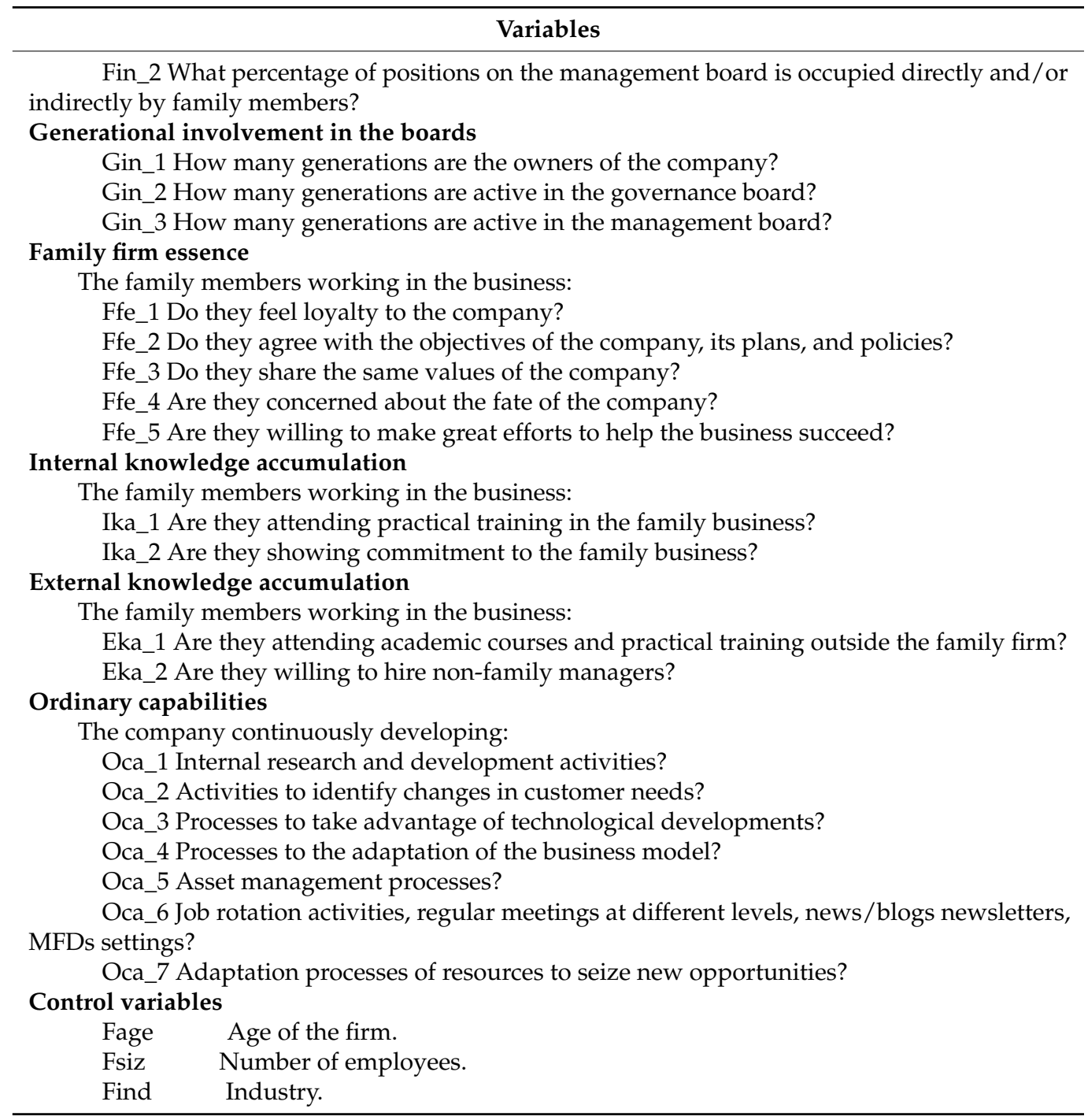

\section{References}

1. Teece, D.J. The Foundations of Enterprise Performance: Dynamic and Ordinary Capabilities in an (Economic) Theory of Firms. Acad. Manag. Perspect. 2014, 28, 328-352. [CrossRef]

2. Cepeda, G.; Vera, D. Dynamic capabilities and operational capabilities: A knowledge management perspective. J. Bus. Res. 2007, 60, 426-437. [CrossRef]

3. Schriber, S.; Löwstedt, J. Reconsidering ordinary and dynamic capabilities in strategic change. Eur. Manag. J. 2020, 38, 377-387. [CrossRef]

4. Arzubiaga, U.; Maseda, A.; Iturralde, T. Exploratory and exploitative innovation in family businesses: The moderating role of the family firm image and family involvement in top management. Rev. Manag. Sci. 2019, 13. [CrossRef]

5. Teece, D.J. Explicating dynamic capabilities: The nature and microfoundations of (sustainable) enterprise performance. Strateg. Manag. J. 2007, 28, 1319-1350. [CrossRef]

6. Family Firm. Institute Global Data Points. Available online: https://web.archive.org/web/20180310111300/http:/ /www.ffi.org: 80/?page=GlobalDataPoints (accessed on 25 March 2020).

7. Chirico, F.; Salvato, C. Knowledge Integration and Dynamic Organizational Adaptation in Family Firms. Fam. Bus. Rev. 2008, 21, 169-181. [CrossRef]

8. Chirico, F.; Nordqvist, M. Dynamic capabilities and trans-generational value creation in family firms: The role of organizational culture. Int. Small Bus. J. 2010, 28, 487-504. [CrossRef]

9. Chirico, F.; Nordqvist, M.; Colombo, G.; Mollona, E. Simulating Dynamic Capabilities and Value Creation in Family Firms. Fam. Bus. Rev. 2012, 25, 318-338. [CrossRef]

10. Barros, I.; Hernangómez, J.; Martin-Cruz, N. A theoretical model of strategic management of family firms. A dynamic capabilities approach. J. Fam. Bus. Strateg. 2016, 7, 149-159. [CrossRef] 
11. Arzubiaga, U.; Diaz-Moriana, V.; Bauweraerts, J.; Escobar, O. Big data in family firms: A socioemotional wealth perspective. Eur. Manag. J. 2020. [CrossRef]

12. Danes, S.M.; Stafford, K.; Haynes, G.; Amarapurkar, S.S. Family Capital of Family Firms. Fam. Bus. Rev. 2009, 22, 199-215. [CrossRef]

13. Camisón-Zornoza, C.; Forés-Julián, B.; Puig-Denia, A.; Camisón-Haba, S. Effects of ownership structure and corporate and family governance on dynamic capabilities in family firms. Int. Entrep. Manag. J. 2020, 16, 1393-1426. [CrossRef]

14. Wang, Y. Environmental dynamism, trust and dynamic capabilities of family businesses. Int. J. Entrep. Behav. Res. 2016, 22, 643-670. [CrossRef]

15. Barros-Contreras, I.; Palma-Ruiz, J.M. Knowledge Accumulation and Its Effects on Organizational Effectiveness in Family Firms. In Intrapreneurship and Sustainable Human Capital. Studies on Entrepreneurship, Structural Change and Industrial Dynamics; Leitão, J., Nunes, A., Pereira, D., Ramadani, V., Eds.; Springer: Cham, Switzerland, 2020; pp. 155-167. ISBN 978-3-030-49410-0.

16. Kang, T.; Baek, C.; Lee, J.-D. Effects of knowledge accumulation strategies through experience and experimentation on firm growth. Technol. Forecast. Soc. Chang. 2019, 144, 169-181. [CrossRef]

17. Denford, J.S. Building knowledge: Developing a knowledge-based dynamic capabilities typology. J. Knowl. Manag. 2013, 17, 175-194. [CrossRef]

18. Lichtenthaler, U. Absorptive capacity, environmental turbulence, and the complementarity of organizational learning processes. Acad. Manag. J. 2009, 52, 822-846. [CrossRef]

19. Serrano-Bedia, A.M.; López-Fernández, M.C.; Garcia-Piqueres, G. Analysis of the relationship between sources of knowledge and innovation performance in family firms. Innovation 2016, 18, 489-512. [CrossRef]

20. Rondi, E.; De Massis, A.; Kotlar, J. Unlocking innovation potential: A typology of family business innovation postures and the critical role of the family system. J. Fam. Bus. Strateg. 2019, 10, 100236. [CrossRef]

21. Forés, B.; Camisón, C. Does incremental and radical innovation performance depend on different types of knowledge accumulation capabilities and organizational size? J. Bus. Res. 2016, 69, 831-848. [CrossRef]

22. Zollo, M.; Winter, S.G. Deliberate Learning and the Evolution of Dynamic Capabilities. Organ. Sci. 2002, 13, 339-351. [CrossRef]

23. Chirico, F. Knowledge Accumulation in Family Firms. Int. Small Bus. J. Res. Entrep. 2008, 26, 433-462. [CrossRef]

24. Gold, A.H.; Malhotra, A.; Segars, A.H. Knowledge Management: An Organizational Capabilities Perspective. J. Manag. Inf. Syst. 2001, 18, 185-214. [CrossRef]

25. Nonaka, I.; Toyama, R.; Nagata, A. A firm as a knowledge-creating entity: A new perspective on the theory of the firm. Ind. Corp. Chang. 2000, 9, 1-20. [CrossRef]

26. Easterby-Smith, M.; Prieto, I.M. Dynamic Capabilities and Knowledge Management: An Integrative Role for Learning? *. Br. J. Manag. 2008, 19, 235-249. [CrossRef]

27. Chrisman, J.J.; Chua, J.H.; Pearson, A.W.; Barnett, T. Family Involvement, Family Influence, and Family-Centered Non-Economic Goals in Small Firms. Entrep. Theory Pract. 2012, 36, 267-293. [CrossRef]

28. Gibb Dyer, W. Examining the "Family Effect" on Firm Performance. Fam. Bus. Rev. 2006, 19, 253-273. [CrossRef]

29. Basco, R. The family's effect on family firm performance: A model testing the demographic and essence approaches. J. Fam. Bus. Strateg. 2013, 4, 42-66. [CrossRef]

30. Arzubiaga, U.; Kotlar, J.; De Massis, A.; Maseda, A.; Iturralde, T. Entrepreneurial orientation and innovation in family SMEs: Unveiling the (actual) impact of the Board of Directors. J. Bus. Ventur. 2018, 33, 455-469. [CrossRef]

31. Calabrò, A.; Torchia, M.; Jimenez, D.G.; Kraus, S. The role of human capital on family firm innovativeness: The strategic leadership role of family board members. Int. Entrep. Manag. J. 2021, 17, 261-287. [CrossRef]

32. Zahra, S.A.; Neubaum, D.O.; Larrañeta, B. Knowledge sharing and technological capabilities: The modearating role of family involvement. J. Bus. Res. 2007, 60, 1070-1079. [CrossRef]

33. Chirico, F.; Sirmon, D.G.; Sciascia, S.; Mazzola, P. Resource orchestration in family firms: Investigating how entrepreneurial orientation, generational involvement, and participative strategy affect performance. Strateg. Entrep. J. 2011, 5, 307-326. [CrossRef]

34. Sirmon, D.G.; Hitt, M.A. Managing Resources: Linking Unique Resources, Management, and Wealth Creation in Family Firms. Entrep. Theory Pract. 2003, 27, 339-358. [CrossRef]

35. Ensley, M.D.; Pearson, A.W. An Exploratory Comparison of the Behavioral Dynamics of Top Management Teams in Family and Nonfamily New Ventures: Cohesion, Conflict, Potency, and Consensus. Entrep. Theory Pract. 2005, 29, 267-284. [CrossRef]

36. Gomez-Mejia, L.R.; Larraza-Kintana, M.; Makri, M. The Determinants of Executive Compensation in Family-Controlled Public Corporations. Acad. Manag. J. 2003, 46, 226-237. [CrossRef]

37. Astrachan, J.H.; Klein, S.B.; Smyrnios, K.X. The F-PEC Scale of Family Influence: A Proposal for Solving the Family Business Definition Problem. Fam. Bus. Rev. 2002, 15, 45-58. [CrossRef]

38. Chua, J.H.; Chrisman, J.J.; Sharma, P. Defining the Family Business by Behavior. Entrep. Theory Pract. 1999, 23, 19-39. [CrossRef]

39. Gómez-Mejía, L.R.; Haynes, K.T.; Núñez-Nickel, M.; Jacobson, K.J.L.; Moyano-Fuentes, J. Socioemotional Wealth and Business Risks in Family-controlled Firms: Evidence from Spanish Olive Oil Mills. Adm. Sci. Q. 2007, 52, 106-137. [CrossRef]

40. Gomez-Mejia, L.R.; Cruz, C.; Berrone, P.; De Castro, J. The Bind that Ties: Socioemotional Wealth Preservation in Family Firms. Acad. Manag. Ann. 2011, 5, 653-707. [CrossRef]

41. Barach, J.A.; Ganitsky, J.B. Successful Succession in Family Business. Fam. Bus. Rev. 1995, 8, 131-155. [CrossRef] 
42. Helfat, C.E.; Finkelstein, S.; Mitchell, W.; Peteraf, M.A.; Singh, H.; Teece, D.J.; Winter, S.G. Dynamic Capabilities: Understanding Strategic Change in Organizations, 1st ed.; Wiley-Blackwell: Malden, MA, USA, 2008; ISBN 978-1405159043.

43. Kusunoki, K.; Nonaka, I.; Nagata, A. Organizational Capabilities in Product Development of Japanese Firms: A Conceptual Framework and Empirical Findings. Organ. Sci. 1998, 9, 699-718. [CrossRef]

44. Kellermanns, F.W.; Eddleston, K.A. Feuding Families: When Conflict Does a Family Firm Good. Entrep. Theory Pract. 2004, 28, 209-228. [CrossRef]

45. Meso, P.; Smith, R. A resource-based view of organizational knowledge management systems. J. Knowl. Manag. 2000, 4, 224-234. [CrossRef]

46. Almeida, P.; Kogut, B. Localization of Knowledge and the Mobility of Engineers in Regional Networks. Manag. Sci. 1999, 45, 905-917. [CrossRef]

47. Lai, K.; Yeung, A.C.L.; Cheng, T.C.E. Configuring quality management and marketing implementation and the performance implications for industrial marketers. Ind. Mark. Manag. 2012, 41, 1284-1297. [CrossRef]

48. Gersick, K.E.; Davis, J.A.; McCollom Hampton, M.; Lansberg, I. Generation to Generation: Life Cycle of Family Business; Harvard Business Review Press: Cambridge, MA, USA, 1997; ISBN 978-0875845555.

49. Zheng, W.; Yang, B.; McLean, G.N. Linking organizational culture, structure, strategy, and organizational effectiveness: Mediating role of knowledge management. J. Bus. Res. 2010, 63, 763-771. [CrossRef]

50. Pérez-Pérez, M.; López-Férnandez, M.C.; Obeso, M. Knowledge, Renewal and Flexibility: Exploratory Research in Family Firms. Adm. Sci. 2019, 9, 87. [CrossRef]

51. Lichtenthaler, U.; Lichtenthaler, E. A Capability-Based Framework for Open Innovation: Complementing Absorptive Capacity. J. Manag. Stud. 2009, 46, 1315-1338. [CrossRef]

52. Jaffe, D.T.; Lane, S.H. Sustaining a Family Dynasty: Key Issues Facing Complex Multigenerational Business- and InvestmentOwning Families. Fam. Bus. Rev. 2004, 17, 81-98. [CrossRef]

53. López-Fernández, M.C.; Serrano-Bedia, A.M.; Pérez-Pérez, M.; Hernández-Linares, R.; Palma-Ruiz, M. A Review of the Academic Literature on Family Business in Spanish. In The Routledge Companion to Family Business; Kellermanns, F.W., Hoy, F., Eds.; Routledge: New York, NY, USA, 2017; pp. 522-548. ISBN 9781317419990.

54. Instituto de Empresa Familiar. La Empresa Familiar en España, 1st ed.; IEF: Madrid, Spain, 2015; ISBN 978-84-608-2119-9.

55. Arosa, B.; Iturralde, T.; Maseda, A. Ownership structure and firm performance in non-listed firms: Evidence from Spain. J. Fam. Bus. Strateg. 2010, 1, 88-96. [CrossRef]

56. Basco, R.; Perez Rodriguez, M.J. Studying the Family Enterprise Holistically: Evidence for Integrated Family and Business Systems. Fam. Bus. Rev. 2009, 22, 82-95. [CrossRef]

57. Sharma, P.; Carney, M. Value Creation and Performance in Private Family Firms. Fam. Bus. Rev. 2012, 25, 233-242. [CrossRef]

58. Kellermanns, F.W.; Eddleston, K.A.; Barnett, T.; Pearson, A. An Exploratory Study of Family Member Characteristics and Involvement: Effects on Entrepreneurial Behavior in the Family Firm. Fam. Bus. Rev. 2008, 21, 1-14. [CrossRef]

59. Zahra, S.A. Entrepreneurial Risk Taking in Family Firms. Fam. Bus. Rev. 2005, 18, 23-40. [CrossRef]

60. Simon, M.; Shrader, R.C. Entrepreneurial actions and optimistic overconfidence: The role of motivated reasoning in new product introductions. J. Bus. Ventur. 2012, 27, 291-309. [CrossRef]

61. Lindow, C.M.; Stubner, S.; Wulf, T. Strategic fit within family firms: The role of family influence and the effect on performance. J. Fam. Bus. Strateg. 2010, 1, 167-178. [CrossRef]

62. Zellweger, T.M.; Kellermanns, F.W.; Eddleston, K.A.; Memili, E. Building a family firm image: How family firms capitalize on their family ties. J. Fam. Bus. Strateg. 2012, 3, 239-250. [CrossRef]

63. Basco, R.; Pérez Rodríguez, M.J. Ideal types of family business management: Horizontal fit between family and business decisions and the relationship with family business performance. J. Fam. Bus. Strateg. 2011, 2, 151-165. [CrossRef]

64. Bryman, A.; Cramer, D. Quantitative Data Analysis with IBM SPSS 17, 18 \& 19: A Guide for Social Scientists; Routledge: London, UK, 2011; ISBN 9780203180990.

65. Campbell, D.T.; Fiske, D.W. Convergent and discriminant validation by the multitrait-multimethod matrix. Psychol. Bull. 1959, 56, 81-105. [CrossRef]

66. Podsakoff, P.M.; MacKenzie, S.B.; Lee, J.-Y.; Podsakoff, N.P. Common method biases in behavioral research: A critical review of the literature and recommended remedies. J. Appl. Psychol. 2003, 88, 879-903. [CrossRef]

67. Kortmann, S.; Gelhard, C.; Zimmermann, C.; Piller, F.T. Linking strategic flexibility and operational efficiency: The mediating role of ambidextrous operational capabilities. J. Oper. Manag. 2014, 32, 475-490. [CrossRef]

68. Grewal, D.; Janakiraman, R.; Kalyanam, K.; Kannan, P.K.; Ratchford, B.; Song, R.; Tolerico, S. Strategic Online and Offline Retail Pricing: A Review and Research Agenda. J. Interact. Mark. 2010, 24, 138-154. [CrossRef]

69. Harman, H.H. Modem Factor Analysis, 3rd ed.; University of Chicago Press: Chicago, IL, USA, 1976; ISBN 978-0226316529.

70. Podsakoff, P.M.; Organ, D.W. Self-Reports in Organizational Research: Problems and Prospects. J. Manag. 1986, 12, 531-544. [CrossRef]

71. Holt, D.T.; Rutherford, M.W.; Kuratko, D.F. Advancing the Field of Family Business Research: Further Testing the Measurement Properties of the F-PEC. Fam. Bus. Rev. 2010, 23, 76-88. [CrossRef]

72. Klein, S.B.; Astrachan, J.H.; Smyrnios, K.X. The F-PEC Scale of Family Influence: Construction, Validation, and Further Implication for Theory. Entrep. Theory Pract. 2005, 29, 321-339. [CrossRef] 
73. Rutherford, M.W.; Kuratko, D.F.; Holt, D.T. Examining the link between "Familiness" and performance: Can the F-PEC untangle the family business theory jungle? Entrep. Theory Pract. 2008, 32, 1089-1109. [CrossRef]

74. Chrisman, J.J.; Chua, J.H.; Litz, R.A. Comparing the Agency Costs of Family and Non-Family Firms: Conceptual Issues and Exploratory Evidence. Entrep. Theory Pract. 2004, 28, 335-354. [CrossRef]

75. Arzubiaga, U.; Maseda, A.; Iturralde, T. Entrepreneurial orientation in family firms: New drivers and the moderating role of the strategic involvement of the board. Aust. J. Manag. 2019, 44, 128-152. [CrossRef]

76. Zellweger, T.M.; Astrachan, J.H. On the Emotional Value of Owning a Firm. Fam. Bus. Rev. 2008, 21, 347-363. [CrossRef]

77. Hair, J.F.; Sarstedt, M.; Pieper, T.M.; Ringle, C. The Use of Partial Least Squares Structural Equation Modeling in Strategic Management Research: A Review of Past Practices and Recommendations for Future Applications. Long Range Plann. 2012, 45, 320-340. [CrossRef]

78. Gefen, D.; Straub, D.W.; Boudreau, M.-C. Structural Equation Modeling And Regression: Guidelines For Research Practice. Commun. Assoc. Inf. Syst. 2000, 4, 1-79. [CrossRef]

79. Peng, D.X.; Lai, F. Using partial least squares in operations management research: A practical guideline and summary of past research. J. Oper. Manag. 2012, 30, 467-480. [CrossRef]

80. Landau, C.; Bock, C. Value Creation through Vertical Intervention of Corporate Centres in Single Business Units of Unrelated Diversified Portfolios-The Case of Private Equity Firms. Long Range Plann. 2013, 46, 97-124. [CrossRef]

81. Moreno, A.M.; Casillas, J.C. Entrepreneurial Orientation and Growth of SMEs: A Causal Model. Entrep. Theory Pract. 2008, 32, 507-528. [CrossRef]

82. Schuster, T.; Holtbrügge, D. Resource Dependency, Innovative Strategies, and Firm Performance in BOP Markets. J. Prod. Innov. Manag. 2014, 31, 43-59. [CrossRef]

83. Ringle, C.M.; Wende, S.; Becker, J.M. SmartPLS 3; SmartPLS GmbH: Bönningstedt, Germany, 2015. Available online: http: //www.smartpls.com (accessed on 2 February 2020).

84. Hair, J.F., Jr.; Sarstedt, M.; Hopkins, L.; Kuppelwieser, G.V. Partial least squares structural equation modeling (PLS-SEM). Eur. Bus. Rev. 2014, 26, 106-121. [CrossRef]

85. Fornell, C.; Larcker, D.F. Evaluating Structural Equation Models with Unobservable Variables and Measurement Error. J. Mark. Res. 1981, 18, 39-50. [CrossRef]

86. Chin, W.W. The Partial Least Squares Approach for Structural Equation Modeling. In Modern Methods for Business Research; Marcoulides, G.A., Ed.; Lawrence Erlbaum Associates, Inc.: Mahwah, NJ, USA, 1998; pp. 295-336.

87. Tenenhaus, M.; Vinzi, V.E.; Chatelin, Y.-M.; Lauro, C. PLS path modeling. Comput. Stat. Data Anal. 2005, 48, 159-205. [CrossRef]

88. Miller, D.; Amore, M.D.; Le Breton-Miller, I.; Minichilli, A.; Quarato, F. Strategic distinctiveness in family firms: Firm institutional heterogeneity and configurational multidimensionality. J. Fam. Bus. Strateg. 2018, 9, 16-26. [CrossRef]

89. Nosé, L.; Korunka, C.; Frank, H.; Danes, S.M. Decreasing the Effects of Relationship Conflict on Family Businesses. J. Fam. Issues 2017, 38, 25-51. [CrossRef]

90. Sciascia, S.; Mazzola, P.; Chirico, F. Generational Involvement in the Top Management Team of Family Firms: Exploring Nonlinear Effects on Entrepreneurial Orientation. Entrep. Theory Pract. 2013, 37, 69-85. [CrossRef]

91. Kellermanns, F.W.; Eddleston, K.A.; Sarathy, R.; Murphy, F. Innovativeness in family firms: A family influence perspective. Small Bus. Econ. 2012, 38, 85-101. [CrossRef]

92. Chua, J.H.; Chrisman, J.J.; Bergiel, E.B. An Agency Theoretic Analysis of the Professionalized Family Firm. Entrep. Theory Pract. 2009, 33, 355-372. [CrossRef]

93. Eisenhardt, K.M.; Martin, J.A. Dynamic Capabilities: What Are They? Strateg. Manag. J. 2000, 21, 1105-1121. [CrossRef]

94. Adler, P.S.; Kwon, S. Social Capital: Prospects for a New Concept. Acad. Manag. Rev. 2002, 27, 17-40. [CrossRef]

95. Chua, J.H.; Chrisman, J.J.; Steier, L.P.; Rau, S.B. Sources of Heterogeneity in Family Firms: An Introduction. Entrep. Theory Pract. 2012, 36, 1103-1113. [CrossRef]

96. Daspit, J.J.; Long, R.G.; Pearson, A.W. How familiness affects innovation outcomes via absorptive capacity: A dynamic capability perspective of the family firm. J. Fam. Bus. Strateg. 2019, 10, 133-143. [CrossRef]

97. Astrachan, J.H. Strategy in family business: Toward a multidimensional research agenda. J. Fam. Bus. Strateg. 2010, 1, 6-14. [CrossRef]

98. Hofstede, G. Culture's Consequences: Comparing Values, Behaviors, Institutions and Organizations Across Nations, 2nd ed.; Sage Publications, Inc.: Thousand Oaks, CA, USA, 2001; ISBN 0803973233.

99. Cruz, C.; Nordqvist, M. Entrepreneurial orientation in family firms: A generational perspective. Small Bus. Econ. 2012, 38, 33-49. [CrossRef]

100. Kellermanns, F.W.; Eddleston, K.A. Corporate Entrepreneurship in Family Firms: A Family Perspective. Entrep. Theory Pract. 2006, 30, 809-830. [CrossRef]

101. Chrisman, J.J.; Sharma, P.; Steier, L.P.; Chua, J.H. The Influence of Family Goals, Governance, and Resources on Firm Outcomes. Entrep. Theory Pract. 2013, 37, 1249-1261. [CrossRef]

102. Cruz, C.; Larraza-Kintana, M.; Garcés-Galdeano, L.; Berrone, P. Are Family Firms Really More Socially Responsible? Entrep. Theory Pract. 2014, 38, 1295-1316. [CrossRef] 